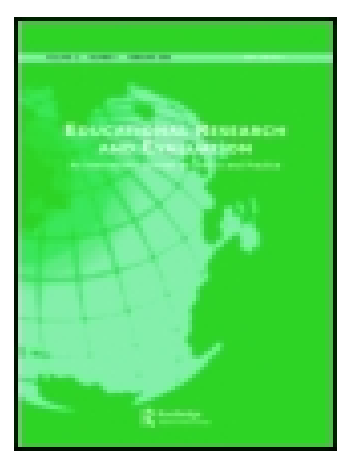

Educational Research and Evaluation

An International Journal on Theory and Practice

ISSN: 1380-3611 (Print) 1744-4187 (Online) Journal homepage: http://www.tandfonline.com/loi/nere20

\title{
Is action research necessarily collaborative? Changing mutuality within a project
}

\section{Francisco Sousa}

To cite this article: Francisco Sousa (2016): Is action research necessarily collaborative? Changing mutuality within a project, Educational Research and Evaluation, DOI:

10.1080/13803611.2016.1247723

To link to this article: http://dx.doi.org/10.1080/13803611.2016.1247723

冓 Published online: 26 Oct 2016.

Submit your article to this journal $[\pi$

Q View related articles $\asymp$

View Crossmark data ־ 